\title{
Re-viewing the role of culture in architecture for sustainable development
}

\author{
Neslihan Dostoğlu* (D)
}

\begin{abstract}
Architecture is most often defined as the art and technique of creating space. The understanding and use of space in a society is the most important means that concretely reflects the cultural system and way of life, which is the sum of all the experiences, talents and values of that society. While the physical environment created by people in history is mostly shaped according to local values, the spaces designed by architects have been the scene of conflict among universal and regional values, especially after the Industrial Revolution, with the development of Modern Architecture. This study which evaluates the architectural approaches adopted after Modern Architecture, within the framework of economic, technological and sociocultural developments in the world and discusses them with their reflections in Turkey, emphasizes the validity of striving for lasting values instead of fashions in architecture. In this context, the issue of culture and identity comes to the fore. Cities have their own unique appearance, physical structure and way of life, as well as a "spirit" that makes them distinctive. The characteristics of the city which make it different from the others constitute "urban identity". Especially in developing countries, many cities face the risk of losing their identity in the process of urban development, which consists of the expansion of the streets and the demolition of buildings that can actually be evaluated. The cultural and natural heritage that makes cities different is also the foundation of urban identity. These values are also a prerequisite for the sustainability of cities. Cultural heritage can be considered not only as a trace of the past, but as a wealth for the future of people. When properly managed, there are many opportunities to create a strong relationship between identity, culture and heritage. Since these opportunities vary in each settlement, different solutions need to be developed. However, it is important that different solutions are produced in a consistent and meaningful integrity, and not as independent initiatives of cities that share the same geography and culture in regional scale. In this process, it is necessary for central administrative bodies, local governments and civil society to work together for an effective and sustainable urban structure.
\end{abstract}

Keywords: architecture, cultural values, sustainability.

\section{Introduction}

It is becoming increasingly more difficult to find environments with distinctive identity, because globalization advocates similar approaches on a worldwide scale, eliminating cultural identities, as values and judgments tend to become similar globally. With the widespread use of television and fax in the 1980s, and mobile phones and the internet in the 1990s, there were rapid developments 
in technology and communication systems, and the Industrial Revolution of the 18th century was replaced by the Information Revolution in the 20th century. In this process, which has continued also in the 21st century, globalization has been effective on various scales, i.e. local, regional, national and global, affecting and changing these environments while also being influenced by them. In fact, it is interesting to note that globalization, which has been criticized for eliminating cultural identities by advocating similar approaches, is also being adopted because it emphasizes some universal values that do not contradict local values. Acknowledging differences in language, religion and culture as a wealth, protecting cultural and natural assets, defending gender equality and saving energy can be given as examples to such values.

In terms of the future of urban development and physical environment, some dilemmas such as globalization/regionalism, universality/nationality, consumption/sustainability need to be understood and interpreted. In this study, relation of architecture and culture will be evaluated in the context of such dilemmas in order to highlight possibilities for creating environments with their distinctive identity.

\section{Globalization and Sustainability}

In the process of globalization, the world is shaped within the framework of the hierarchy of core, semi-periphery and periphery countries, and some cities in core countries play an important role in controlling developments in the world (Wallerstein, 1974). In order to understand the dilemma of globalization and regionalism, the concept of sustainability must be emphasized in particular. The word 'sustainability' was first used at a conference organized by the United Nations in 1970. However, the most commonly used definition of this concept is contained in the Brundtland Report published by the World Commission on Environment and Development in the UK in 1987. Sustainability in this report was defined as "development that meets the needs of the present without compromising the ability of future generations to meet their own needs." (Pugh, 1996) (Figure 1).

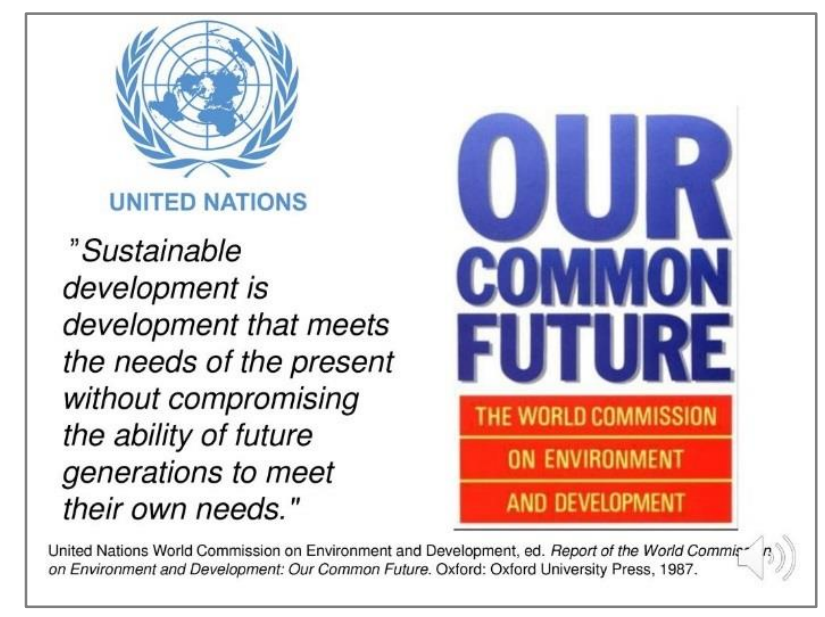

Figure 1 The Brudtland Report (United Nations World Commission, 1987)

For a long time, sustainability was addressed only in its physical dimensions. However, subsequent assessments have shown that sustainability has environmental, social/ cultural and economic dimensions. One thing that should be emphasized at this point is that the different dimensions of the concept of sustainability are related. Environmental sustainability means the protection of natural resources and ecosystems. It is also interpreted as ecological sustainability. Social sustainability involves maintaining and developing the social position and ensuring the balance and cultural diversity of social systems; cultural sustainability is related with preserving and developing cultural values such as cultural heritage, cultural life and cultural activities, which should be passed on to future generations; and economic sustainability refers to ensuring the maximum 
flow related to economic well-being while preserving existing savings. (Pugh, 1996, Nystrom \& Fudge, 1999)

It should be noted that part of the physical environment may comprise different functions and meanings according to the socio-cultural, economic and technological changes that occur in the historical process. Therefore, the physical characteristics of the environment can be more Page| 159 permanent than its functions. In this context, it turns out that environmental, social, cultural and economic dimensions should be evaluated together in order to improve the quality of life in a city and ensure urban sustainability.

In spite of all the technological and social developments improving the conditions in various fields during the twentieth century, this can be considered as a period of turmoil. Two world wars took place with all their sufferings, urbanization accelerated, and the phenomenon of globalization affected the whole world as a result of rapid developments in technology and communication systems. When the situation at the beginning of the twenty-first century is examined, it can be observed that the world population continues to increase, and urbanization caused by the proliferation of the number of cities and the growth of existing cities in terms of both population and size continues at full speed. This means that all related parties, including central and local authorities, non- governmental organizations and the civil society itself, need to find alternative ways to make urban environments more sustainable and livable and to increase the sense of belonging by attributing unique, distinctive identity to these environments. Cultural factors become significant in this process.

\section{Culture: Definition and Context}

Culture is the total way of living, comprising material and spiritual values, talents and skills, arts and traditions of a society (Güvenç, 1997). Based on this definition, it can be emphasized that the importance given to cultural heritage can help shape the environment with greater confidence, with more identity and through social solidarity. Cultural heritage can also be considered as a new economic opportunity as it creates new sources of business and income. At the same time, it helps to create new forms of partnership between the public sector, the private sector and civil society, and leads to new opportunities in directing social risks.

Cultural tourism has become an important alternative type of tourism for many countries in the world. This is a form of tourism that is favored in terms of preserving cultural values as well as its income-generating effect. At present, a significant share of cultural tourism in the world is made up of natural and cultural assets on the UNESCO World Heritage List. In fact, areas that are included in the World Heritage List are considered to have a rising value. However, in cases where the balance between protection and use is not achieved, these regions with outstanding values are adversely affected. It can be observed that some areas are saturated in terms of usage today and even suffer from negative image, noise, environmental and infrastructure problems. The concept of globalized tourism in such areas has a negative effect on the traditional life culture. In this context, management plans including vision studies for the future should be made and implemented in relation to the areas that are included in UNESCO World Heritage List.

The World Heritage List consists of cultural and natural entities that are deemed to have an important value for the whole world, by complying with the 'World Heritage Criteria' which the countries (state parties) signing the "Convention Concerning the Protection of the World Cultural and Natural Heritage" guarantee to protect. In order for an area to be included as a cultural or natural heritage in the UNESCO World Heritage List, it must meet at least one of the 6 cultural and 4 natural criteria set by the World Heritage Committee, which measures outstanding universal value. It is also expected to meet the conditions in terms of authenticity and integrity. After 2000, UNESCO began to look for the preparation and implementation of "Site Management Plan"s as a prerequisite for the inclusion of protected assets and areas on the World Heritage List. Thus, the 
specific entity or area is aimed to be protected with all of its characteristics and with the participation of all parties concerned (Feilden, B. M. \& Jokilehto, J., 1993).

In this context, the World Heritage Committee first declared 12 sites meeting one or more of the above-mentioned criteria, as World Heritage Site, in 1978. As of 2020, the number of heritage sites on the World Heritage List has reached a total of 1121, of which 869 are cultural, 39 are mixed and 213 are natural. The number of sites on the list changes according to the World Heritage Committee meetings that take place annually (Figure 2 and Figure 3 ).

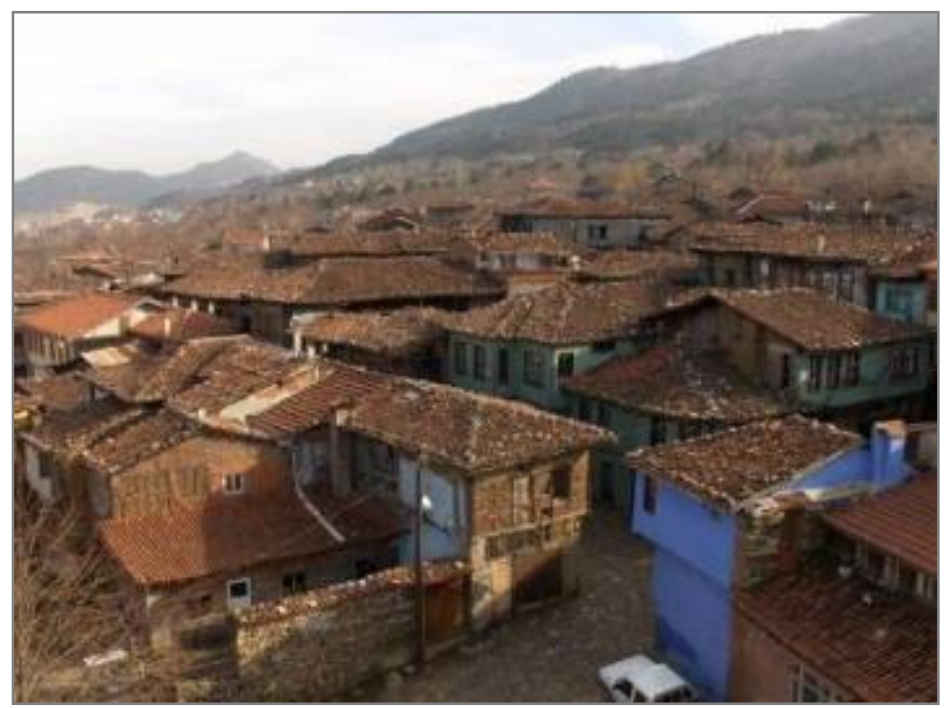

Figure 2 Cultural Heritage Example on UNESCO World Heritage List, Cumalıkızık, Bursa (Metropolitan Municipality of Bursa Archives)

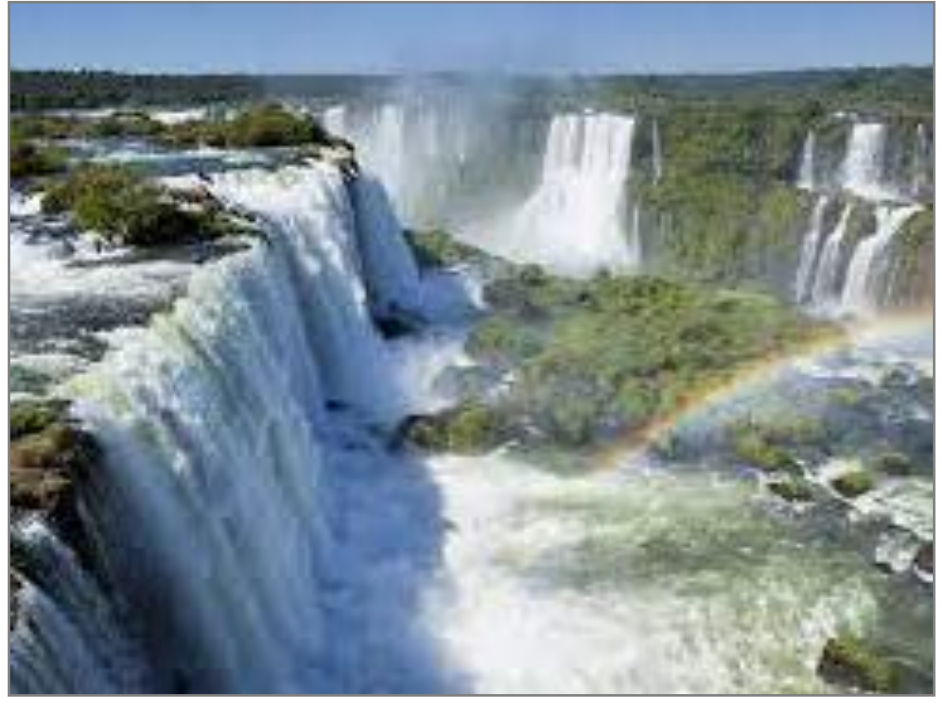

Figure 3 Natural Heritage Example on UNESCO World Heritage List, Iguazu Falls, Argentina / Brazil (URL-1).

\section{Different Architectural Approaches Related to Social and Cultural Values}

Architecture is most often defined as the art and technique of creating space. The understanding and use of space in a society is the most important means that concretely reflects the cultural system and way of life, which is the sum of all the experiences, talents and values of that society. While the physical environment created by people in history is mostly shaped according to local values, the spaces designed by architects have been the scene of conflict among universal and regional values, especially after the Industrial Revolution. At this point, it is useful to remember the definition of vernacular architecture. Paul Oliver, an architectural historian who studied vernacular 
architectural traditions around the world since the early 1960s, describes vernacular architecture as "...comprising the dwellings and all other buildings of the people". In Oliver's words, "All forms of vernacular architecture are built to meet specific needs, accommodating the values, economies and ways of life of the cultures that produce them." (Oliver, 1997) (Figure 2) It is the architecture of the people and the architecture produced by the people, which is different from the architecture for the people, a concept developed after the Industrial Revolution.

At this point, the changes taking place in the architectural milieu after the Industrial Revolution will be reviewed. In fact, the Industrial Revolution can be considered as a turning point in architectural history, as it prepared the way to the development of Modern Architecture. In order to understand Modern Architecture, it is necessary to re-evaluate the concept of 'modernism'. The word 'modern' or Latin 'modernus' was first used in the 5th century to identify the period when Christianity was officially accepted as different from the Roman and Pagan past. Modernism in architecture emerged with the technical, social and cultural changes related with the Industrial Revolution, which began in the middle of the 18th century (Habermas, 1990). With the development of new materials and techniques and the formation of new requirements, the innovations first seen on railways and bridges and initially implemented under the leadership of engineers and technicians began to take effect in buildings (Benevolo, 1977).

In late 19th century, the Art Nouveau movement in Europe, which under the leadership of John Ruskin and Henry van de Velde, included a new sense of style to replace the imitation of old styles, but remained on a more ornamental scale, on the one hand, and the rational architectural approach based on steel construction and modern techniques, that emerged in Chicago in the United States and developed under the leadership of William Le Baron Jenney, Daniel Burnham and Louis Sullivan, on the other hand, laid the foundations of modern architecture. Starting in the 1920s, the principles of modern architecture were developed by architects such as Le Corbusier, Walter Gropius and Richard Neutra. These principles, which can be summarized as decoration-free simplicity, expression of function in form, belief in technology, universal solutions free of historical references, were embodied in the first five of the ten CIAM meetings organized from 1928 to 1956 with the participation of representative architects from many countries. As stated in the De Stijl manifesto published in 1918, ensuring "international unity in life, art, culture, either intellectually or materially" was the aim of avant-garde architecture (Conrads, 1975). It is possible to draw parallels between this approach developing in architecture and the capital's desire to create an international sovereignty through technological progress.

Indeed, in the discourse of Modern Architecture, architecture was considered as a functional object like other industrial products, and an approach that advocated the universal application of prototypes was adopted in general. Le Corbusier's famous phrase "A house is a machine to live in" clearly expresses this approach. (Figure 4, 5) Le Corbusier, who finished his book Towards a New Architecture with a photo of a pipe, wanted to point out that architecture should have the same values as such a product with both personal and universal standards. Le Corbusier, believing in the role of the architect as a hero and a savior, concluded his book with the following sentence: "Architecture or Revolution. Revolution can be avoided." (Le Corbusier, 1970) (Figure 6). 


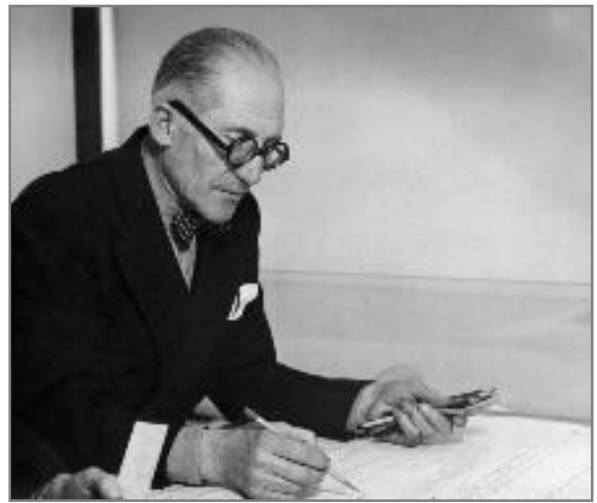

Figure 4 Le Corbusier (URL-2)

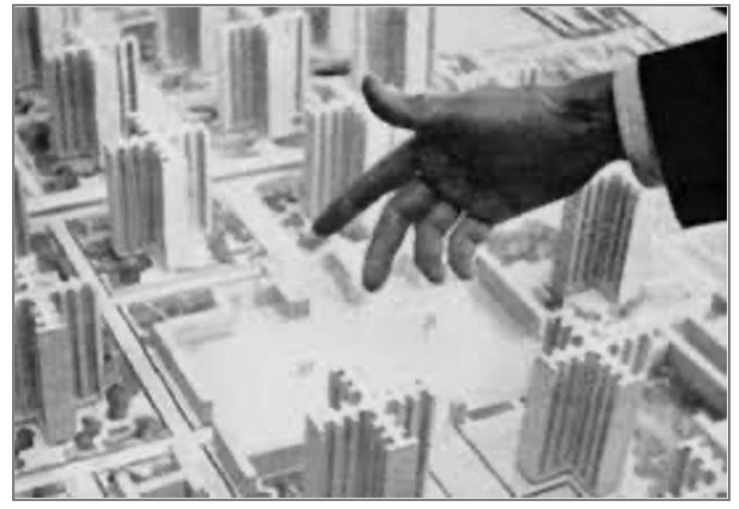

Figure 5 Le Corbusier's Voisin Plan Model, 1924 (URL-3)

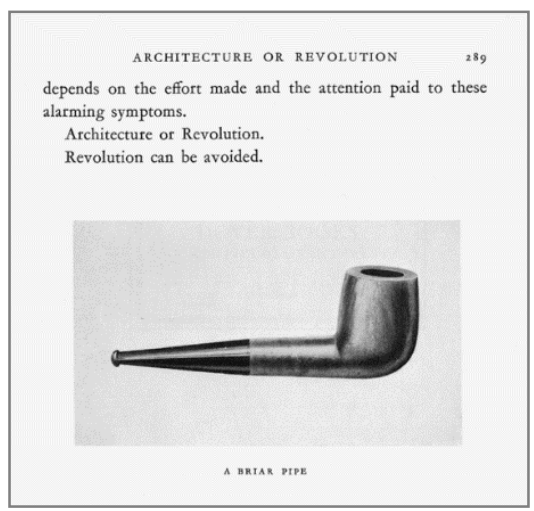

Figure 6 The pipe in Le Corbusier's book, (Le Corbusier, 1970)

While Modern Architecture is generally defined according to the above-mentioned principles, we should indicate that there are different approaches within this general framework. There are even cases when the same architect has adopted different styles in various periods. In this context, it should be emphasized that in Post-Modern Architecture discourse, views that often consider Modern Architecture as a homogeneous approach and call it a complete failure, ignore that this movement has contributed to the development of new design methods and social concerns, although not comprehensive enough.

There were also some conscious critical approaches towards Modern Architecture. The first substantial criticism came from some young architects within CIAM (Congrès Internationaux d'Architecture Moderne). As a result of the discussions at the 6th CIAM Congress held in 1947, after a ten-year interval due to World War II, architects such as Aldo van Eyck, Alison and Peter Smithson, (Figure 7) Jacob Bakema, Georges Candilis formed the Team 10 Group and advocated an approach that emphasized identity rather than universality, place rather than space, circumstance rather than era, the hierarchical elements of public life such as house-street-district-city, rather than treating the city as divided into autonomous areas, i.e. zones based on four functions of dwelling- work - recreation -transportation, as advocated by CIAM (Figure 8,9). However, the views of TEAM 10 group related with social life remained on a general scale and did not provide an adequate basis for healthy design proposals. 


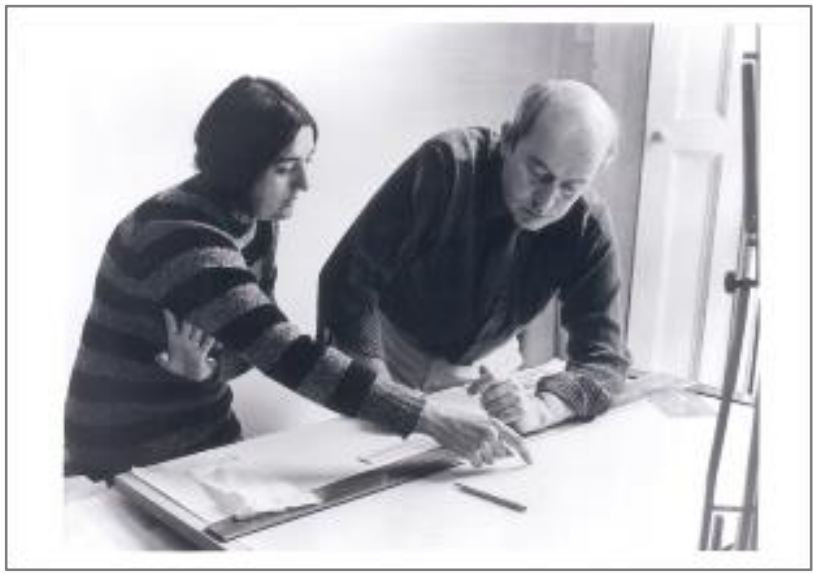

Figure 7 Alison and Peter Smithson (URL-4)

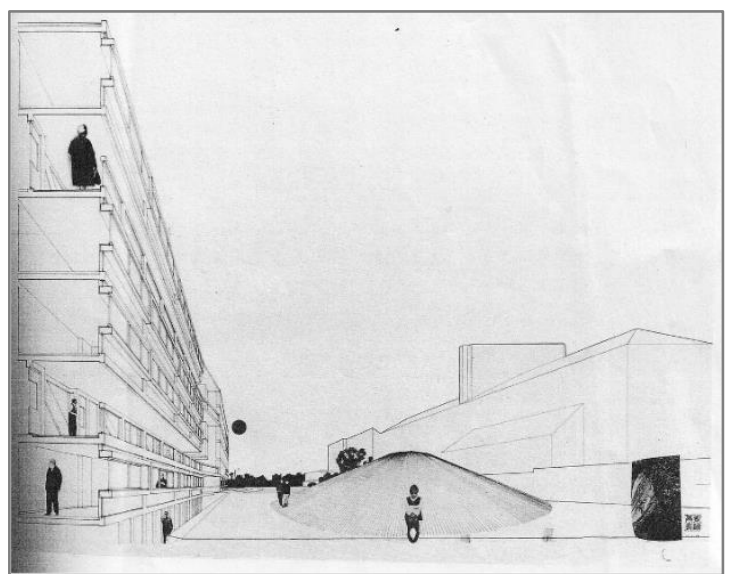

Figure 8 Alison and Peter Smithson, initial drawing of Robin Hood Gardens (URL-5)

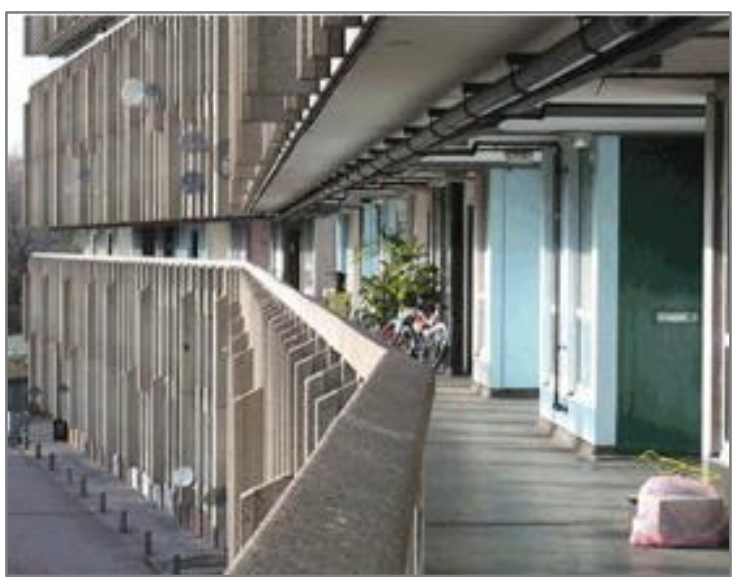

Figure 9 Robin Hood Gardens, Street in the Air (URL-5)

Finally, two books published in the early 60 s formed the premises of the views that shook the foundations of Modern Architecture towards the end of that decade. One of them is Kevin Lynch's book The Image of the City published in 1960. (Figure 10) In this book, Lynch talks about images that develop in the public memory of the inhabitants of the city, arguing that in order for a city to have identity, structure and meaning, and to prevent alienation, it must have physical qualities such as paths, edges, districts, nodes and landmarks, which he defines as city image elements in general.

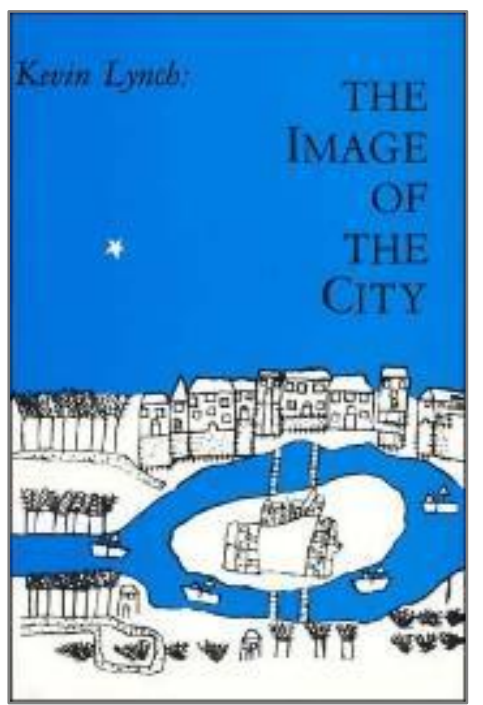

Figure 10 The Image of the City (Lynch, K., 1960) 
Jane Jacobs's book The Death and Life of Great American Cities, published in 1961, criticizes orthodox modern urban planning and architectural design, arguing that conditions such as multiple functions and multipurpose use, low blocks, a mix of old and new buildings and sufficient human density must be provided for vitality, diversity and economic wealth in cities. (Figure 11) In this sense, while both books glorify practical, picturesque experiences against the utopian approach of Modern Architecture aimed at finding universal solutions to urban and architectural problems, we can indicate that the first book has influenced the New Classicist approach that developed after 1966, with concepts such as "public memory" and "image", and the second book has influenced the Eclectic-Populist approach with its emphasis on the ordinary and familiar.

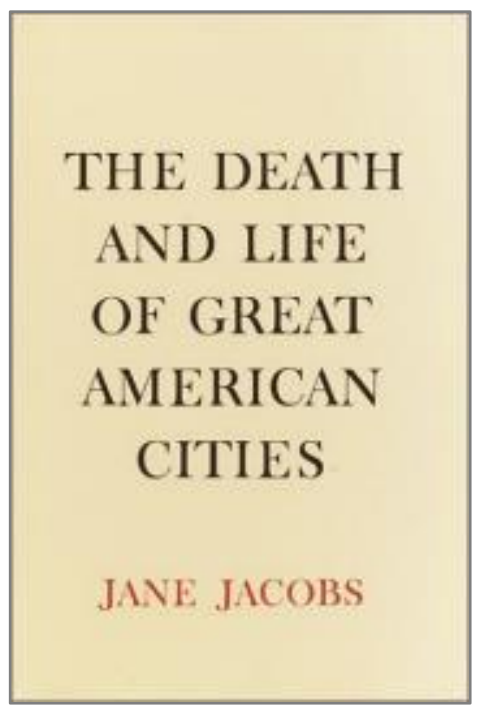

Figure 11 The Death and Life of Great American Cities (Jacobs, J., 1961)

1966 is a turning point for the criticism of Modern Architecture. With the publication of Robert Venturi's Complexity and Contradiction in Architecture in USA in 1966, (Figure 12) and the publication of Aldo Rossi's The Architecture of the City in Italy in 1966, (Figure 13) a new era began in architectural discourse. However, unlike previous criticisms, Venturi's approach advocating references to multiple meanings in design, and Rossi's idea that permanent forms can lead to new uses and new meanings over time, which includes the reinterpretation of the types in public memory, laid the foundations for the approach known as "postmodernism" in architectural discourse. It should be emphasized that while approaches that could be an alternative to modern architecture were mentioned, the title "postmodern" was not used in these books.

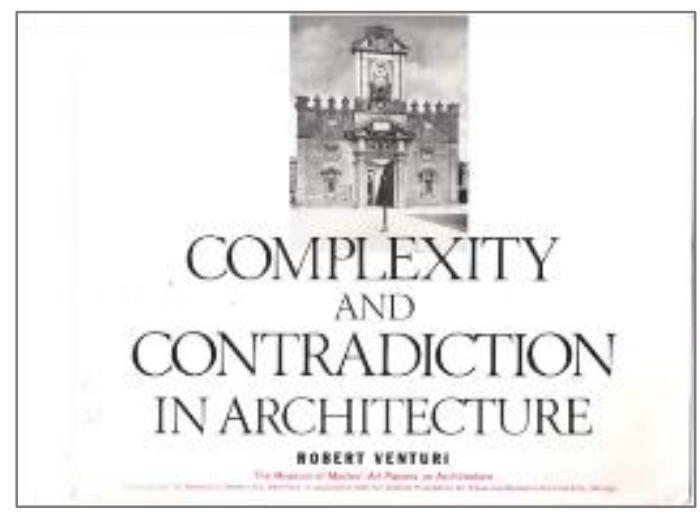




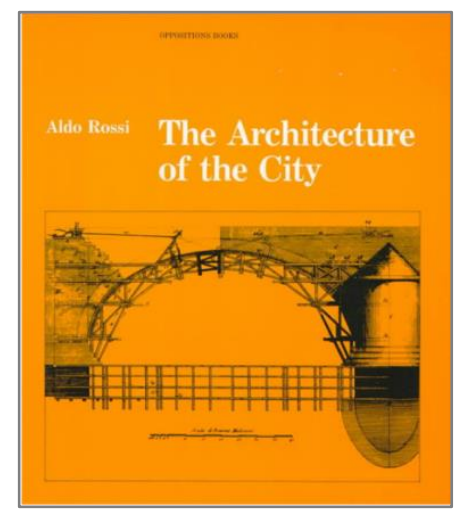

Figure 13 The Architecture of the City (Rossi, A., 1982)

As Zeka points out, the "post-" prefix contains the dimension of "a subsequency, a rebellion". The concept of post-modernism also means a reckoning with modernity above all. The labyrinths, mirrors, allegories, diversions, riddles, mythologies, parodies in Borges's writings were an inspiration for postmodernism (Zeka, 1990).

Postmodern Architecture has developed in parallel with economic, technological and sociocultural changes in the world, similar to Modern Architecture. In fact, after the 60s, which is defined as the post-industrial period, industrial society was replaced by information society and labor/production paradigm was converted into information paradigm. As it is not possible to talk about homogeneous Modern Architecture, it is not possible to define Post-Modern Architecture as a single approach. In this context, Zeka points out that postmodernism can be defined as "heterogeneity, polyphony, division, as well as an attitude that affirms misunderstandings, misconceptions, delusions, and even sees them as the basis of legitimacy" (Zeka, 1990, 12).

In short, in the pluralistic critical environment, which began with the launch of the Team 10 Group in 1947 and was later maintained by architects described as 'Post-Modern', a general interest in history, natural and regional features, social values and identity began, but many architects continued this interest as if following a fashion, ignoring the philosophical dimensions of the approach (Dostoğlu, 1995).

\section{Architectural Developments in Turkey After The 1980's}

When we consider the developments after the 1980s in Turkey within the framework outlined above, it is possible to discuss three main architectural approaches in a pluralistic table. The first can be summarized as adopting architectural approaches popular in developed countries, the second is focusing on local resources in Anatolia, and the third can be summarized as aiming to produce lasting values by addressing the unique conditions in Turkey together with the universal developments in architecture.

In the first group, there is a wide range from Merih Karaaslan to Şefik Birkiye, who have adopted the eclectic, populist approach of Post-Modern Architecture. (Figure 14) Among the reflections of the new classical approach in Turkey, we can cite Semra-Özcan Uygur's Ankara Yüksek ihtisas Hospital Annex as an example. When we examine the recent Turkish architecture within this framework, it is possible to state that Postmodernism was adopted in Turkey, often without the ideological accumulation in the West, by producing 'kitsch' in the form of a binary structure of foreign and domestic types. In addition to the architects who have adopted Post-Modern approaches in the West literally, architects such as Sezar Aygen, who interprets Modernist tendencies, and architects inspired by the deconstructive approaches in the West can be considered as another category within this group. 


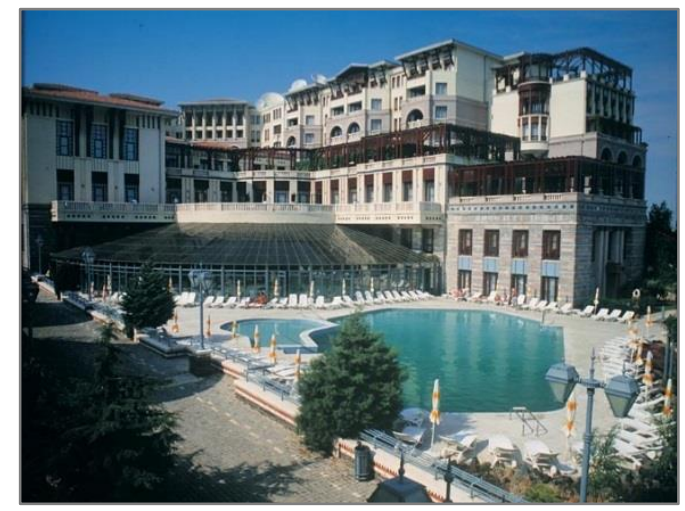

Page | 166

Figure 14 Şefik Birkiye, Klassis Hotel (URL-6)

The second architectural approach in Turkey focuses on local resources. The best example for this is the architectural approach of Turgut Cansever, as applied in Demir Vacation Village particularly, which has been defined by some people as "platonic", "moralist", "boring", "conservative" (Figure 15).

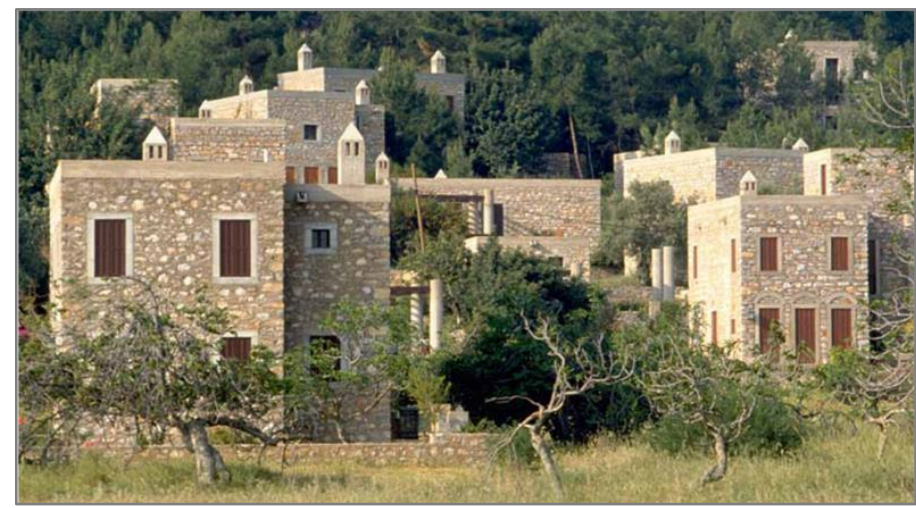

Figure 15 Turgut Cansever, Demir Vacation Village (URL-7)

As an example of the third approach, we can point out Mehmet Konuralp and Salih Sağlamer's Sagra Residence and Guest-House buildings in Ordu, (Figure 16) Şaziment-Neşet Arolat's Kervansaray Termal Hotel in Bursa, Cengiz Bektaş's Olbia Sosyal Özek project, (Figure 17) Han Tümertekin's B2 house. (Figure 18) In these examples, it can be indicated that a response to the universal / regional dilemma in the handling of the place is sought in a philosophical way. In the Sagra project, the architects evaluated the seranders, which were traditionally built on poles in order to protect products such as hazelnuts and corn, from animals and ground moisture in the Black Sea Region, from a typological point of view in the buildings of Sagra, a modern hazelnut marketer, and designed them with contemporary materials and techniques by interpreting the serander type.

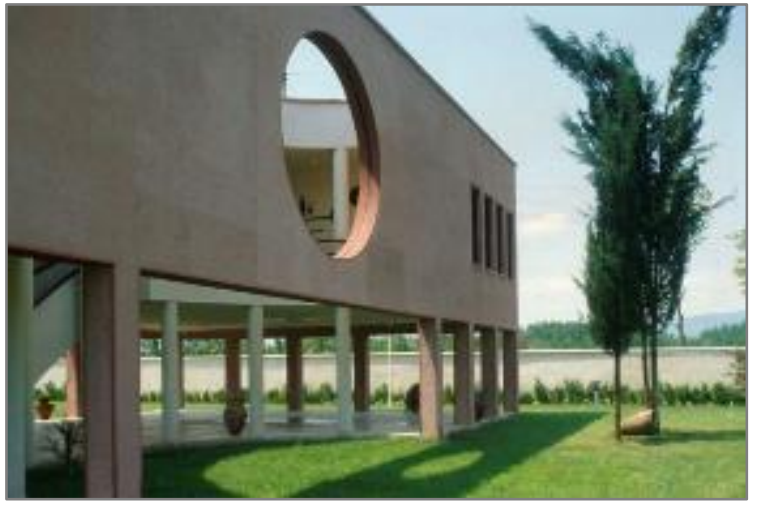

Figure 16 Mehmet Konuralp and Salih Sağlamer, Sagra Residence and Guesthouse, Ordu (URL-8) 


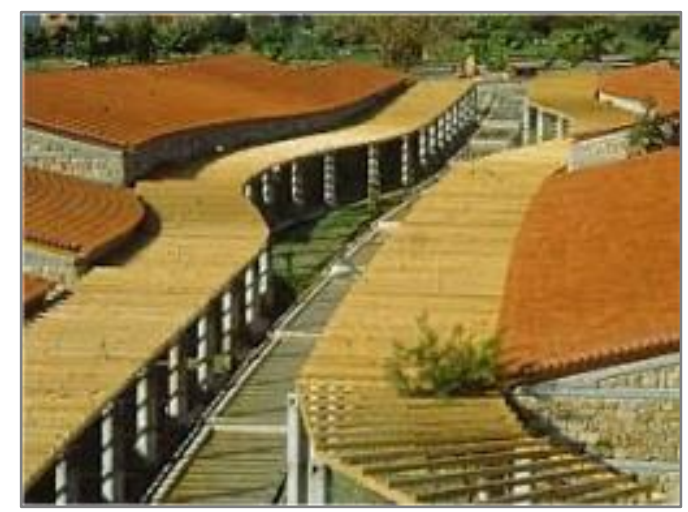

Figure 17 Cengiz Bektaş, Olbia Sosyal Özek project, Akdeniz University (URL-9)

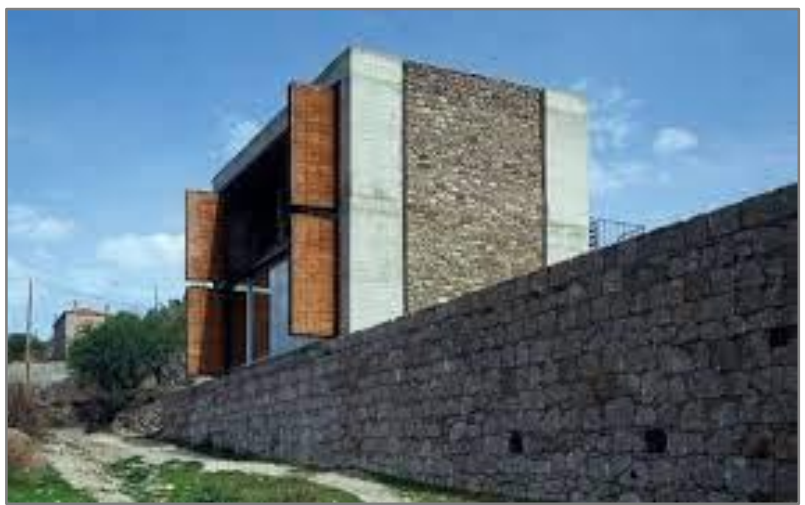

Figure 18 Han Tümertekin, B-2 House (URL-7)

\section{Evaluation}

The architectural approaches that developed in late 1940s, based on the criticism of modernism gradually gained legitimacy on a universal scale with forms evoking "Disneyland Architecture". However, as Huxtable points out, the approaches of postmodernists, who have accused modernists with their phrase "Less is a bore", have become boring after a while. (Huxtable, 1985) In this context, the number of people who define postmodernism as a fashion and postmodernist architects as fashion designers is not small. Indeed, Post-Modernity was treated by many architects not as a new perspective on space and culture, but as a formal attitude that should be copied.

Starting in the 1990s, critical regionalism, which he has been pioneered by Frampton since the 1960s, Rowe's "Collage City" idea, which advocates the unity of traditional and modern, and the Deconstructivist approach, which can be summarized by the concepts of "discontinuity", "uncertainty", "currency", "insolvency" developed by architects such as Eisenmann, Tschumi and Hadid inspired by Russian Constructivists, appear as the three main critical attitudes in architectural discourse. In short, concepts such as pluralism and diversity brought about by the post-modern situation and the basis of freedom create the possibilities for the establishment of consumer society culture, as well as the criticism and transformation of this culture (Güzer, 1994).

This study which evaluates the architectural approaches adopted after Modern Architecture, within the framework of economic, technological and socio-cultural developments in the world and discusses them with their reflections in Turkey, emphasizes the validity of striving for lasting values instead of fashions in architecture. In this context, the issue of culture and identity comes to the fore. Cities have their own unique appearance, physical structure and way of life, as well as a "spirit" that makes them distinctive. The characteristics of the city which make it different from the others constitute "urban identity". Especially in developing countries, many cities face the risk of losing their identity in the process of urban development, which consists of the expansion of the streets and the demolition of buildings that can actually be evaluated. 
The cultural and natural heritage that makes cities different is also the foundation of urban identity. These values are also a prerequisite for the sustainability of cities. Cultural heritage can be considered not only as a trace of the past, but as a wealth for the future of people. When properly managed, there are many opportunities to create a strong relationship between identity, culture and heritage. Since these opportunities vary in each settlement, different solutions need to be developed. However, it is important that different solutions are produced in a consistent and meaningful integrity, and not as independent initiatives of cities that share the same geography and culture in regional scale. In this process, it is necessary for central administrative bodies, local governments and local people to work together for an effective and sustainable structure.

On the other hand, buildings that have been repaired or restored without thoroughly addressing their functionality are sometimes unusable and remain empty. Therefore, it is important to protect and revive buildings and urban spaces of historical importance by giving contemporary functions without disturbing the characteristics of the physical environment for historical, social and economic reasons. Cultural heritage does not only involve the physical environment, but also the ways in which it is perceived and used. Therefore, new functions should be given to historical environments and buildings after extensive evaluations, respecting their integrity, character and form. (Ahunbay, 1996) This process is of great importance for historical continuity, sustainability, and social awareness about identity, improvement in quality of life and economic rationality.

Finally, as the closing remarks of this article, I would like to re-view the relationship of architecture and culture, which is important for sustainable environments. The basic occupation of the architectural profession, evolving since $3000 \mathrm{BC}$, is "space", which is a formation that is affected by the characteristics of the specific period, socio-cultural environment and economic values. Space can be defined as a phenomenon created by the bounded space and the bounding elements together, determined by movement, and existing with light (Kuban, 1984). In addition to the closed 'indoors' bounded by the building elements, there are also 'outdoors' defined by elements such as buildings, trees, walls and roads. In fact, the concepts of interior and exterior are not independent from each other; on the contrary, they are intertwined, that is, architecture is more dependent on environmental conditions than any other field of art. In other words, it is necessary to examine the built environment not as an individual architectural product, but as a spatial pattern that exists as a result of the combination of open and closed spaces. As Erzen emphasizes, humans, unlike animals, have always sought a place for their actions, and they have defined an area with boundaries for their actions, even in open spaces, stating that "the physical elements that make up the space gain meaning with cultural values and the form of the spaces gives clues about how a culture is in a relationship with the environment (Erzen, 2013).

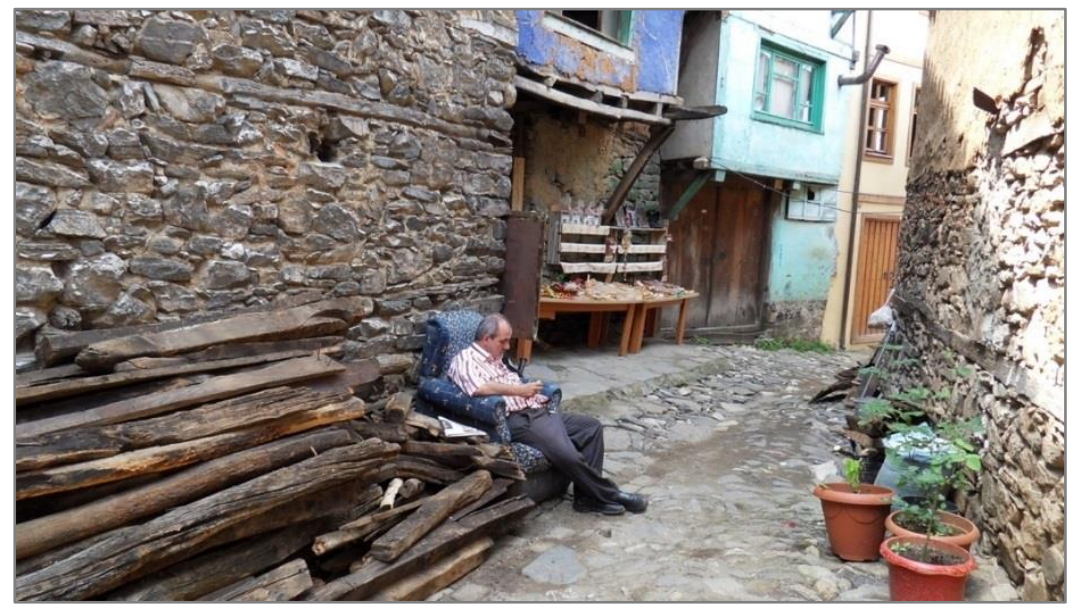

Figure 19 The Dialogue of Culture and Environment in Cumalıkızık (Author) 


\section{References}

Ahunbay, Z. (1996). Tarihi Çevre Koruma ve Restorasyon, İstanbul: YEM Yayın.

Benevolo, L. (1977). History of Modern Architecture, vol. 1, Cambridge: The MIT Press.

Conrads, U. (1975). Programs and Manifestoes on 20th-Century Architecture, Cambridge, Mass.: The MIT Press.

Page| 169 Dostoğlu, N. (1995). “Modern Sonrası Mimarlık Anlayışları”, Mimarlık, no. 263, 46-50.

Erzen, J. N., (2013). Mimarlık Dünyayı Yaşamak, Ankara: ODTü Mimarlık Fakültesi Basım İşliği.

Feilden, B. M. and Jokilehto, J. (1993). Management Guidelines for World Cultural Heritage Sites, Rome: ICCROM.

Frampton, K. (1980). Modern Architecture: A Critical History, New York: Oxford University Press.

Güvenç, B., (1997). Kültürün ABC'si, İstanbul: Yapı Kredi Yayınları.

Güzer, C. A. (1994). 'Las Vegas'ın Öğretemedikleri', Mimarlık, no.260.

Habermas, J. (1990). "Modernlik: Tamamlanmamış Bir Proje", ref. Zeka, N,, Postmodernizm, İstanbul: Kıyı Yayınları.

Huxtable, A., ref. Harries, K. (1985). 'Modernity's Bad Conscience', AA Files, n:10.

Jacobs, J. (1961). The Death and Life of Great American Cities, New York: Vintage Books.

Kuban, D., (1984). Mimarlık Kavramları: Mimarlığın Kuramsal Sözlüğüne Giriş, İstanbul: Çevre Yayınları.

Le Corbusier (1970). Towards a New Architecture, Londra: The Architectural Press.

Lynch, K. (1960). The Image of the City, Cambridge, Mass.: The M.I.T. Press.

Lyotard, J.F. (1979) La Condition Postmoderne, ret. Zeka, N.

Metropolitan Municipality of Bursa Archives

Nystrom, L. and Fudge, C. eds. (1999). City and Culture: Cultural Processes and Urban Sustainability, Stockholm: The Swedish Urban Environment Council.

Oliver, P. (1997). Encyclopedia of Vernacular Architecture of the World: Cultures and Habitats, Cambridge: Cambridge University Press, 1997

Pugh, C., ed. (1996). Sustainability, the Environment and Urbanization, Londra: Earthscan Publications, Ltd.

Rossi, A. (1982). The Architecture of the City, Cambridge, Mass.: The MIT Press.

Rowe, C. \& Koetter, F. (1984). Collage City, Cambridge, Mass.: The MIT Press.

United Nations World Commission on Environment and Development ed. (1987). Report of the World Commission on Environment and Development: Our Common Future, Oxford: Oxford University Press.

Venturi, R. (1977). Complexity and Contradiction in Architecture, New York: The Museum of Modern Art.

Wallerstein, I. (1974). The Modern World System. Vol. 1, Capitalist Agriculture and the Origins of the European World-Economy in the Sixteenth Century. New York: Academic Press.

Zeka, N. (1990). 'Yolları Çalallanan Bahçe, Aynalı Gökdelenler, Dil Oyunları ve Robespierre', Zeka, N., deri., Postmodernizm, İstanbul: Kıyı Yayınları.

URL-1 www.mynet.com /Iguazu-selalesi-nerede

URL-2 www.news.artnet.com

URL-3 www.researchgate.net

URL-4 www.archdaily.com

URL-5 https://en.wikiarquitectura.com/

URL-6 www.otelklassisresort

URL-7 www.arkitektuel.com

URL-8 www.archnet.com

URL-9 www.arkiv.com.tr

\section{Resume}

Prof. Dr. Neslihan Dostoglu studied architecture at Middle East Technical University in Turkey (B. Arch. 1978, M. Arch. 1981), and received her Ph.D. in Architecture from University of Pennsylvania in USA in 1986. After working at Uludag University in Bursa for sixteen years, she started teaching at Istanbul Kültür University and became the Dean of the Faculty of Architecture, and the Head of MIDEKON, the Council of Deans of Faculties of Architecture in Turkey and Northern Cyprus. Dostoglu, who is the Manager of UNESCO World Heritage Site in Bursa, is the author and the editor of several books. She has also contributed articles to many national and international publications and has received various awards in architectural design competitions. Her study areas are architectural design, architectural education, revitalization and sustainability, and site management. 